\title{
PENGARUH LOGOTHERAPY TERHADAP KEPUTUSASAAN PADA NARAPIDANA WANITA DI LEMBAGA PERMASYARAKATAN WANITA KELAS IIA BANDUNG
}

\author{
${ }^{1}$ Sri Wulan Lindasari, ${ }^{2}$ Iyus Yosep, ${ }^{3}$ Titin Sutini \\ ${ }^{1}$ Bagian Keperawatan Jiwa Akper Kabupaten Sumedang \\ ${ }^{2}$ Fakultas Keperawatan Universitas Padjadjaran \\ ${ }^{3}$ Fakultas Keperawatan Universitas Padjadjaran
}

Email:

\begin{abstract}
Abstrak
Angka kriminalitas setiap tahunnya mengalami peningkatan. Seseorang yang melakukan tindakan kriminalitas, dapat menimbulkan berbagai macam permasalahan yaitu kerugian materil maupun imateril. Dengan tinggal di lapas, narapidana wanita akan mengalami loss of family, loss of control, loss of model dan lack of stimulation sehingga dapat mengakibatkan keputusasaan. Dampak dari keputusasaan apabila tidak segera ditangani dapat mengakibatkan depresi dan bunuh diri. Logotherapy adalah psikoterapi yang bertujuan untuk membantu individu menemukan makna hidup pada situasi apapun termasuk dalam situasi yang tidak menyenangkan. Tahapan dari logotherapy ini dilakukan 4 sesi yaitu pengkajian, stimulasi imajinasi kreatif, memproyeksikan makna hidup dalam kehidupan sehari-hari dan evaluasi. Tujuan penelitian adalah untuk mengetahui pengaruh logotherapy terhadap keputusasaan pada narapidana wanita di Lapas wanita kelas IIA Bandung. Desain penelitian yang digunakan adalah quasi experimental pre-post test non equivalent control group. Populasi dalam penelitian ini adalah semua narapidana wanita yang mengalami keputusasaan dan tidak mengalami depresi berat sebanyak 57 orang. Cara pengambilan sampel adalah secara total sampling. Penelitian dilakukan terhadap 57 responden yang terdiri dari 29 orang kelompok intervensi dan 28 kelompok kontrol. Alat pengumpulan data menggunakan kuesioner Beck Hopelessness Scale (BHS). Analisa data univariat yaitu dengan menghitung distribusi frekuensi dan sentral tendensi. Analisa bivariat menggunakan Paired t-test dan Chi-Square. Hasil penelitian menunjukkan bahwa adanya pengaruh logotherapy pada kelompok intervensi sebelum dan setelah diberikan logotherapy dengan nilai p value 0,001 dan t hitung 14,61. Rekomendasi hasil penelitian adalah perlunya pelaksanaan logotherapy dalam program pembinaan mental para narapidana yang mengalami keputusasaan di lapas wanita.
\end{abstract}

Kata kunci: Keputusasaan, logotherapy, narapidana wanita

\begin{abstract}
The crime rate has increased every year. Someone who commits criminal acts can cause various problems for the actors themselves are material and immaterial losses. The women who stay in the prison will loss of family, loss of control, loss of models and lack of stimulation. The existence of these things can lead the inmates to hopeless. If hopelessness did not treate properly, it can lead to depression and suicide. Logotherapy is a psychotherapy that aims to help individual find meaning in life in any situation, including in an unpleasant situation. The logotherapy has four sessions that assessment, the stimulation of creative imagination, projecting the meaning of life in everyday life and evaluation.The aim of this study are to obtain a description about the Influence of logotherapy to women inmates who have hopelessnes in prison Bandung IIA class women. The method of this study is quasi-experiment pre-post test non equivalent with control group. The sample was obtained by total sampling. The study was conducted on 57 respondents consisting of 29 respondents in the intervention group and 28 respondents in the control group. The data was collect used Beck Hopelessness Scale (BHS) questionare and was analyzed with univariate descriptive by calculating the frequency distribution and central tendency. The paired t-test and Chi-Square were utilized to analized bivariate data. The result showed that there was a significant influence in the intervention group before and after being given logotherapy with $p$ value 0.001 and $t=14,61$. The recommendation in this study is the implementation of logotherapy in mental coaching program in inmates' women who have hopelessness experiance has needed.
\end{abstract}

Keywords: Hopelesness, logotherapy, inmates' women 


\section{PENDAHULUAN}

Lembaga pemasyarakatan merupakan tempat untuk melaksanakan pembinaan terhadap orang-orang yang dijatuhi hukuman penjara berdasarkan keputusan pengadilan. Perubahan status menjadi narapidana merupakan stressor yang dapat menimbulkan berbagai masalah psikologis seperti stress, cemas, frustasi, depresi, resiko bunuh diri, harga diri rendah dan putus asa (Nedderman, Underwood \& Hardy, 2010). Hal ini disebabkan karena mereka mengalami loss of family loss of control, loss of model dan lack of stimulation (Cook, et all, 1990 dalam Charlotte \& Jane (2012).

Individu yang merasa pesimis dan cenderung menganggap dirinya negatif setelah mengalami suatu peristiwa lebih berisiko untuk mengalami keputusasaan (Brozina \& Abela, 2006). Menurut Forintos \& Rozsa (2010) dampak dari keputusasaan dapat menyebabkan depresi dan bunuh diri. Menurut NANDA (2012) faktor yang berhubungan dengan keputusasan seperti perasaan tertinggal, kehilangan kepercayaan terhadap nilai, pembatasan aktivitas yang menimbulkan isolasi dan stress yang berkepanjangan (Dunn, 2010).

Salah satu tindakan keperawatan untuk mengatasi keputusasaan yaitu dengan logotherapy (Stuart \& Laraia, 2005). Hal ini sejalan dengan hasil penelitian sebelumnya yaitu logotherapy dapat menurunkan tingkat keputusasaan pada narapidana anak dan remaja, sedangkan pada narapidana wanita belum pernah dilakukan penelitian ini. Logotherapy merupakan tindakan perawatan kelompok yang menjadi intervensi pada penelitian ini. Logotherapy dapat mengubah pandangan atau penilaian negatif setiap anggota kelompok terhadap permasalahan hidup yang dialaminya menjadi positif dengan melalui proses penemuan/pencarian makna dan nilai-nilai berharga di dalamnya serta harapan-harapan yang masih dimiliki. Proses logotherapy yang diterapkan pada narapidana wanita akan menghasilkan pikiran positif, perasaan bahagia/nyaman serta perilaku adaptif sehingga hidup menjadi lebih bermakna dan tingkat keputusasaan berkurang.

\section{TUJUAN PENELITIAN}

\section{Tujuan Umum}

Mengetahui pengaruh logotherapy terhadap tingkat keputusasaan pada narapidana wanita di Lembaga Pemasyarakatan Wanita Kelas IIA Bandung.

\section{Tujuan Khusus}

a. Mengetahui tingkat keputusasaan narapidana wanita pada kelompok intervensi dan kelompok kontrol sebelum pemberian logotherapy di lapas Wanita Kelas IIA Bandung.

b. Mengetahui perubahan tingkat keputusasaan narapidana wanita pada kelompok intervensi dan kelompok kontrol setelah pemberian logotherapy di Lapas Wanita kelas IIA Bandung.

c. Mengetahui perubahan tingkat keputusasaan narapidana wanita pada kelompok intervensi sebelum dan setelah pemberian logotherapy di Lapas Wanita Kelas IIA Bandung.

d. Mengetahui perubahan tingkat keputusasaan narapidana wanita pada kelompok kontrol antara pre test dan post test di Lapas Wanita Kelas IIA Bandung. 


\section{METODE PENELITIAN}

Desain yang digunakan dalam penelitian ini adalah "Quasi experimental pre-post test non equivalent control group" dengan intervensi logotherapy.

Pelaksanaan penelitian ini dilakukan selama 5 minggu, mulai dari tanggal 4 Mei sampai 5 Juni 2015. Terapi diberikan sebanyak 6 kali pertemuan dengan tiap pertemuan sebanyak satu sesi, dengan pelaksanaan kegiatan setiap satu minggu sekali. Satu sesi dilakukan selama 45-60 menit. Selama pemberian logotherapy, terapi yang diberikan berupa sesi pengkajian, stimulasi imaginatif yang kreatif, memproyeksikan makna hidup dalam kehidupan sehari-hari dan evaluasi atau terminasi. Variabel dependent dalam penelitian ini adalah keputusasaan narapidana wanita. Pengukuran variabel dependent ini dilakukan sebelum dan sesudah diberikan intervensi.

Variabel independent dalam penelitian ini adalah intervensi logotherapy yang diberikan pada narapidana wanita. Intervensi logotherapy terdiri dari 4 (empat) sesi yaitu. Sesi 1 mengidentifikasi perubahan dan masalah yang terjadi pada pasien dan mengembangkan kesadaran terhadap nilainilai yang dimiliki dengan mengidentifikasi respon-respon yang timbul terhadap pertanyaan yang diajukan. Sesi 2: Menstimulasi imajinasi kreatif, yaitu terapis mengembangkan pertanyaan ke arah harapan dan makna hidup yang didambakan peserta. Sesi 3 terapis membantu peserta mengurangi ketidakyakinan akan kelemahan diri yang dirasakan dengan cara memberikan reinforcement positif atas kemampuan peserta untuk menemukan dan mempelajari makna hidup dari setiap tindakan yang dilakukan. Sesi 4 yaitu mengevaluasi pencapaian makna hidup setelah seluruh sesi dilakukan.
Populasi dalam penelitian ini adalah seluruh narapidana wanita yang berada di Lapas wanita Kelas IIA Bandung sebanyak 302 orang. Dari 302 orang narapidana kemudian dilakukan screening dengan menggunakan instrumen Beck Hopelessness Scale (BHS) untuk mengukur tingkat keputusasaan dan kuesioner BDI (The Beck Depression Inventory) untuk pengukuran tingkat depresi.

Dari hasil screening di dapatkan jumah sampel sebanyak 57 orang yang mengalami keputusasaan dan tidak mengalami depresi. Pengambilan sampel dalam penelitian ini adalah dengan menggunakan total sampling yaitu semua narapidana wanita yang berada di lapas wanita Kelas IIA Bandung yang memenuhi kriteria dengan jumlah 57 orang. Pemilihan responden untuk menentukan kelompok intervensi dan kelompok kontrol dilakukan dengan cara pengocokan dimana responden yang mempunyai nomor urut ganjil termasuk dalam kelompok intervensi sedangkan yang mempunyai nomor urut genap termasuk dalam kelompok kontrol. Setelah dilakukan pengocokan maka didapatkan jumlah kelompok intervensi sebanyak 29 orang dan kelompok kontrol 28 orang.

Instrumen yang digunakan untuk mengukur tingkat keputusasaan dengan menggunakan instrumen Beck Hopelessness Scale (BHS) yang sudah baku dan dikembangkan oleh Aaron Beck sejak tahun 1974. Instrumen ini dirancang untuk mengukur 3 aspek utama keputusasaan yaitu dimensi kognitif mencakup pikiran negatif terkait dengan harapan masa depan seseorang, dimensi afektif melibatkan perasaan negatif terhadap masa depan seseorang dan dimensi motivasi menunjukkan keyakinan bahwa kegagalan dan keberhasilan adalah independent tindakan seseorang (harapan ketidakberdayaan). Instrumen ini terdiri dari 20 pertanyaan. 
Untuk penilaian keputusasaan berdasarkan penilaian BHS apabila jumlahnya 0-3 normal, 4-8 keputusasaan ringan, 9-14 keputusasaan sedang dan 15 - 20 keputusasaan berat.

Kuesioner pengukuran tingkat depresi pada penelitian ini menggunakan skala depresi beck yang disebut BDI (The Beck Depression Inventory). Skala BDI ini terdiri dari 21 kelompok item yang menggambarkan 21 kategori sikap dan gejala depresi. Jumlah nilai 0-15 dianggap normal, jumlah nilai 16-30 depresi ringan, 31-45 depresi sedang dan jumlah nilai 46-63 depresi berat.

Variabel dengan data kategori yaitu pendidikan, pekerjaan, status perkawinan dan jenis kasus menggunakan distribusi frekuensi dan proporsi, sedangkan variabel dengan data numerik yaitu usia dan lama masa tahanan maka dianalisis menggunakan sentral tendensi yang disajikan dalam mean, median, standar deviasi, nilai minimal maksimal dengan confident interval sebesar 95\%. Untuk analisa bivariat dilakukan uji parametrik Paired $T$ Test. Sedangkan kalau data tidak berdistribusi normal dilakukan uji non parametik MannWhitney U-Test. Sedangkan untuk uji homogenitas menggunakan Levene test.

\section{HASIL PENELITIAN}

\section{Karakteristik Responden}

Dari hasil penelitian menunjukkan bahwa usia rata-rata pada kelompok kontrol 38,43 tahun dengan rentang usia paling muda 19 tahun dan paling tua 62 tahun dan pada kelompok intervensi usia rata-rata 39,45 tahun dengan rentang usia paling muda 20 tahun dan paling tua 60 tahun. Sedangkan rata-rata masa tahanan pada kelompok kontrol 3,71 tahun dengan rentang paling sedikit masa tahanan 1 tahun dan paling lama masa tahanan 8 tahun, sedangkan pada kelompok intervensi rata-rata masa tahanan 3,14 tahun dengan rentang paling sedikit masa tahanan 1 tahun dan paling lama masa tahanan 8 tahun. Untuk pendidikan narapidana wanita lebih banyak dengan pendidikan tinggi yaitu 29 $(50,9 \%)$, pekerjaan narapidana wanita lebih banyak yang bekerja yaitu $38(66,7 \%)$, status perkawinan narapidana wanita lebih banyak yang menikah yaitu $30(52,6 \%)$ dan jenis kasus narapidana wanita lebih banyak yaitu narkoba 30 orang $(29,8 \%)$.

Tabel 1.

Perubahan tingkat keputusasaan narapidana wanita pada kelompok intervensi dan kelompok kontrol sebelum pemberian logotherapy di lapas Wanita Kelas IIA Bandung

\begin{tabular}{ccccc}
\hline Kelompok & $\mathbf{N}$ & Mean & $\mathbf{Z}$ & $\begin{array}{c}\mathbf{p} \\
\text { value }\end{array}$ \\
\hline Intervensi & 29 & 29,17 & $-0,08$ & 0,93 \\
Kontrol & 28 & 28,82 & \\
\hline
\end{tabular}

Berdasarkan tabel 1 di atas menunjukkan bahwa hasil uji statistik dengan menggunakan uji Mann-Whitney didapatkan nilai $p$ value 0,93 . Nilai signifikansi pretest kelompok intervensi dan kontrol lebih besar dari 0,05 yang berarti $\mathrm{H} 0$ diterima dengan kata lain tidak ada perbedaan tingkat keputusasaan antara kelompok intervensi dan kelompok kontrol sebelum dilakukan terapi.

Tabel 2.

Perubahan tingkat keputusasaan narapidana wanita pada kelompok intervensi dan kelompok kontrol setelah pemberian logotherapy di lapas Wanita Kelas IIA Bandung

\begin{tabular}{ccccccccc}
\hline Kelompok & N & Mean & SD & Min & Max & SE & t & p value \\
\hline Intervensi & 29 & 3,86 & 1,60 & 4,00 & 13,00 & 0,30 & $-3,06$ & 0,003 \\
Kontrol & 28 & 5,29 & 1,90 & 3,00 & 9,00 & 0,40 & & \\
\hline
\end{tabular}


Berdasarkan tabel 2. dapat dilihat bahwa tingkat keputusasaan narapidana wanita pada kelompok intervensi dan kelompok kontrol setelah pemberian logotherapy dengan nilai p value adalah 0,003, dengan kata lain ada perbedaan tingkat keputusasaan antara kelompok intervensi dan kelompok kontrol setelah dilakukan terapi.

Tabel 3.

Perubahan tingkat keputusasaan narapidana wanita pada kelompok intervensi sebelum dan setelah pemberian logotherapy di lapas Wanita Kelas IIA Bandung

\begin{tabular}{cccccccc}
\hline $\begin{array}{c}\text { Kelompok } \\
\text { Intervensi }(\mathbf{N}=29)\end{array}$ & Mean & SD & Min & Max & SE & t & $\begin{array}{c}\mathbf{p} \\
\text { value }\end{array}$ \\
\hline Sebelum & 7,66 & 1,82 & 5 & 13 & 0,26 & 14,61 & 0,001 \\
Setelah & 3,86 & 1,59 & 2 & 7 & &
\end{tabular}

Dari tabel 3. dapat dilihat bahwa skor rata-rata keputusasaan narapidana wanita sebelum dilakukan logotherapy adalah 7,66 sedangkan setelah logotherapy menjadi 3,46. Dilihat angka signifikasi pada kelompok intervensi sebelum dan sesudah logotherapy nilai $p$ value yaitu 0,001 , dengan kata lain terdapat perbedaan tingkat keputusasaan sebelum dan sesudah logotherapy pada kelompok intervensi.

Tabel 4.

Perubahan tingkat keputusasaan narapidana wanita pada kelompok kontrol antara pre and post test di lapas Wanita Kelas IIA Bandung

\begin{tabular}{cccccccc}
\hline $\begin{array}{c}\text { Kelompok } \\
\text { kontrol }(\mathbf{N}=\mathbf{2 8})\end{array}$ & Mean & SD & Min & Max & SE & t & $\begin{array}{c}\mathbf{p} \\
\text { value }\end{array}$ \\
\hline Sebelum & 7,86 & 2,38 & 4,00 & 13,00 & 0,43 & 6,04 & 0,001 \\
Setelah & 5,26 & 1,90 & 3,00 & 9,00 & & \\
\hline
\end{tabular}

Dari tabel 4. dapat dilihat bahwa skor ratarata keputusasaan narapidana wanita pada saat pre test adalah 7,86 sedangkan setelah post test skor rata-rata keputusasaan narapidana wanita menjadi 5,26. Dilihat dari nilai $p$ value pada kelompok kontrol sebelum dan sesudah test yaitu 0,001 . Oleh karena angka sigifikansi lebih kecil dari 0,05, maka Ho ditolak dengan kata lain terdapat perbedaan tingkat keputusasaan sebelum dan sesudah test pada kelompok kontrol.

\section{PEMBAHASAN}

Tingkat keputusasaan narapidana wanita pada kelompok intervensi dan kelompok kontrol sebelum pemberian logotherapy

Hasil penelitian menunjukkan bahwa tidak terdapat perbedaan tingkat keputusasaan yang signifikan antara kelompok intervensi dan kelompok kontrol sebelum pemberian logotherapy dengan nilai $p$ value $0,93>0,05$. Kondisi tersebut menjelaskan bahwa tingkat keputusasaan pada kelompok intervensi dengan kelompok kontrol ada dalam keadaan homogen.

Ada beberapa faktor yang dapat menyebabkan kesamaan tersebut adalah dapat dilihat dari kesamaan karakteristik responden seperti usia dari masing-masing kelompok berada dalam tahap masa dewasa muda/awal, pekerjaan karena sebagian besar responden termasuk orang-orang yang bekerja dan status perkawinan yang sebagian besar responden sudah menikah.

Penelitian yang dilakukan oleh Gil \& Gilbar (2001) mengatakan bahwa keputusaan lebih banyak terjadi pada usia produktif dan semakin berkurang dengan bertambahnya usia. Masa dewasa awal adalah merupakan tahapan yang banyak konflik/masalah. Jika 
Seseorang tidak dapat beradaptasi atau menyesuaikan diri terhadap situasi baru tersebut dan tidak dapat menyelesaikan masalah/konflik akan mengakibatkan masalah psikologis seperti perasan tertekan, cemas, bingung dan putus asa. Hal ini sejalan dengan hasil penelitian bahwa ternyata yang banyak mengalami keputusasaan adalah responden yang ada dalam masa produktif/dewasa awal.

Seseorang yang tidak mempunyai pekerjaan atau pengangguran merupakan faktor resiko terjadinya depresi. Pekerjaan mempunyai hubungan dengan keputusasaan. Penelitian yang dilakukan oleh Arslan, Celebioglu dan Tezel (2009) mengatakan bahwa pasien yang bekerja memiliki skor keputusasaan yang lebih tinggi dibandingkan dengan yang tidak bekerja. Selama berada di lapas, narapidana yang bekerja akan kehilangan pekerjaanya sehingga mereka tidak bisa melakukan aktivitas seperti biasanya. Hawari (2001) mengatakan bahwa masalah pekerjaan merupakan sumber stress pada diri seseorang dimana ketika seseorang yang asalnya bekerja tiba-tiba harus berhenti merupakan stressor. Apalagi ketika seseorang harus berada di lembaga pemasyarakatan yang secara otomatis berbagai kegiatan menjadi terbatas. Hal ini sejalan dengan hasil penelitian bahwa sebagian besar responden yang mengalami keputusasaan adalah responden yang bekerja.

Status perkawinan berpengaruh terhadap perilaku seseorang baik positif maupun negatif. Bambang (2008) mengatakan bahwa seseorang yang sudah menikah akan merasakan kenyamanan hidup berdampingan dengan pasangannya. Ketika seseorang harus berada dalam lapas maka kenyamanan itu akan berubah karena mereka hidup tidak berada di tengah-tengah keluarga sehingga kalau mekanisme koping dari seseorang tersebut tidak bagus dapat mengakibatkan masalah psikologis juga yang salah satunya adalah putus asa. Hal ini sesuai dengan hasil penelitian bahwa sebagian besar dari responden adalah yang sudah menikah.

\section{Perubahan keputusasaan pada kelompok intervensi dan kelompok kontrol setelah mendapatkan logotherapy}

Berdasarkan hasil uji statistik dari tabel 2 diperoleh adanya perbedaan penurunan tingkat keputusasaan pada responden antara kelompok intervensi dan kelompok kontrol setelah pemberian logotherapy yang signifikan dengan nilai $\mathrm{p}$ value 0,003 . Berdasarkan hasil dokumentasi pelaksanaan logotherapy sesi 1, didapatkan bahwa 90\% anggota kelompok dapat mengemukakan masalahnya terkait dengan keputusasaan. Mereka merasa menyesal telah melakukan tindak kejahatan dan bosan dengan hidup di penjara, sehingga membuat kehidupan mereka menjadi hampa, kosong, bosan, tidak berdaya, putus asa dan tidak bermakna. Keadaan yang dialami responden tersebut disebut existensial vakum. Menurut Farby dalam Marshall (2010) seseorang yang kehilangan makna dalam hidupnya akan berada pada existansial vakum dan selanjutnya mengalami existansial frustration. Existensial frustration adalah respon emosional terhadap proses kehilangan makna dan tujuan dalam hidup.

Pada penelitian yang dilakukan pada kelompok intervensi, didapatkan bahwa responden menunjukkan terjadi penurunan tingkat keputusasaan yang lebih baik (tiga kali lipat) dibandingkan dengan kelompok kontrol. Hal ini dikarenakan anggota kelompok memiliki motivasi dan keinginan kuat untuk bermakna dalam situasi apapun yang merupakan sikap secara keseluruhan responden sejak awal mulai kegiatan logotherapy. Faktor lainnya adalah responden telah berhasil menemukan makna dari situasi yang dialaminya masing-masing dan hal itu 
menimbulkan penilaian diri yang positif seperti merasa berarti, merasa berguna, merasa ada hikmahnya dan bisa menyelesaikan masalahnya. Dukungan anggota kelompok berupa reinforcement positif dan penerimaaan positif juga ikut berkontribusi dalam meningkatkan kebermaknaan hidup.

Keadaan tersebut berbeda dengan kelompok kontrol dimana penurunan tingkat keputusasaan tidak terlalu banyak atau hanya satu kali lipat dibandingkan dengan kelompok intervensi. Hal ini disebabkan karena kelompok kontrol tidak dilakukan logotherapy sehingga mereka tidak di tuntun untuk belajar bagaimana memaknai hidup dimana logotherapy memandang kemampuan/ potensi yang sama merupakan hal unik dan istimewa karena di dalamnya mengandung makna khusus yang berbeda setiap orang.

\section{Perubahan tingkat keputusasaan responden pada kelompok intervensi sebelum dan setelah mendapatkan logotherapy}

Hasil penelitian menunjukkan bahwa terdapat perubahan tingkat keputusasaan pada responden kelompok intervensi dan kelompok kontrol sebelum dan setelah dilakukan logotherapy dengan nilai $\mathrm{p}$ value 0,001 $<0,05$. Kondisi tersebut menjelaskan bahwa intervensi penelitian logotherapy berhasil menurunkan tingkat keputusasaan sehingga responden dapat menemukan kebermaknaan hidup.

Perawat mempunyai andil sangat besar dalam membantu narapidana mengatasi keputusasaan sebagai akibat banyaknya stressor berada di lembaga pemasyarakatan. Perawat yang dapat membantu mengatasi keputusasaan pada narapidana secara tidak langsung telah membantu meningkatkan kualitas hidup karena narapidana dapat memaknai hidupnya kembali. Tindakan keperawatan dengan pemberian psikoterapi menjadi salah satu bagian yang bisa diberikan secara mandiri untuk mengatasi keputusasaan. Salah satu jenis terapi dalam mengatasi keputusasaan adalah dengan melakukan logotherapy. Pemberian logotherapy ini bertujuan untuk meningkatkan makna hidup narapidana yang mengalami keputusasaan.

Pada logotherapy responden dilatih untuk mampu berfikir mengenali dan memahami potensi dan nilai-nilai positif dari diri sebagai sumber makna dalam menghadapi nilai-nilai negatif dan permasalahan hidup. Prinsip logotherapy adalah tidak menghilangkan secara langsung pikiran negatif yang di alami melainkan harus menghadapinya dengan memunculkan harapan dan menggali potensi dalam kehidupan kita serta melakukan proses pendekatan dan penentuan makna dibalik pikiran negatif atau masalah tadi (Bastaman, 2007).

Tujuan yang ingin dicapai dalam pemberian logotherapy ini adalah hidup bahagia dan bermakna dengan permasalahan yang ada. Namun proses pendekatan dan pencarian makna dalam suatu permasalahan kehidupan merupakan proses yang rumit, tidak semua orang dapat menemukannya. Proses itu akan menjadi lebih mudah dengan kita terbiasa melatih potensi dan sumber makna yang di dalam diri setiap individu.

Menurut penulis keberhasilan logotherapy terhadap penurunan tingkat keputusasaan responden dikarenakan terapis telah melaksanakan kegiatan sesuai dengan tahapan-tahapan yang seharusnya. Adapun keempat tahapan tersebut adalah sesi 1 mengemukakan masalah yang berkaitan dengan terjadinya keputusasaan, sesi 2 stimulasi imajinasi kreatif, sesi 3 menghadirkan situasi yang memberikan makna dalam kegiatan sehari-hari dan sesi 4 
evaluasi/terminasi (Hutzel, 1990). Berdasarkan dokumentasi dari hasil kegiatan buku kerja yang telah diisi oleh masingmasing responden diperoleh bahwa hampir 90\% responden dapat mengungkapkan masalah dan menemukan makna dari permasalahan yang dihadapi sehingga menunjukkan terjadinya penurunan tingkat keputusasaan yang lebih baik daripada sebelumnya.

Dalam pelaksanaan logotherapy sesi 1 dan 2, terapis selalu memberikan stimulus pertanyaan yang sifatnya terbuka sehingga responden mempunyai kebebasan untuk mengungkapkan pemikirannya. Selanjutnya terapis mengarahkan pola pikir responden ke arah nilai-nilai makna hidup. Pada saat sesi 1, beberapa dari responden selama mengungkapkan permasalahannya ada yang terlihat sedih, murung bahkan ada yang sampai menangis karena teringat kembali dengan apa yang sudah dilakukan sebelumnya yang berkaitan dengan tindak kejahatan. Apalagi banyak dari responden yang harus meninggalkan keluarga padahal sehingga fungsi sebagai ibu dan istri harus ditinggalkan. Dalam situasi seperti ini perawat penting sekali merapkan teknikteknik komunikasi terapeutik seperti empati, bersikap terbuka, listening, reframing dan sebagainya.

Pada sesi 2 ketika responden dituntun untuk bisa memaknai hidup dengan harapan yang diinginkan, sebagian besar dari responden menyatakan bahwa sudah bosan hidup di dalam lapas, mereka ingin hidup ditengahtengah keluarga dan bisa menjalankan hidup sebagai mana mestinya seperti sebelum masuk ke dalam lapas. Tetapi ada juga beberapa responden yang mengatakan bahwa Dia bingung dengan apa yang akan dilakukannya ketika nanti sudah keluar dari lapas karena merasa malu dengan istilah mantan narapidana, dimana narapidana itu mempunyai stigma yang jelek di masyarakat. Tetapi hampir sebagian responden selama berada di lapas itu dapat menemukan hikmahnya seperti dapat melatih kesabaran, meningkatkan keimanan serta mempererat persaudaraan.

Pada sesi ketiga responden dilatih untuk melakukan atau mendemonstrasikan kegiatankegiatan harian yang dapat memunculkan makna/hikmah di dalamnya. Untuk hasilnya dapat dilihat dari buku unjuk kerja yang responden isi bahwa sebagian besar dari mereka sudah melakukan berbagai macam kegiatan yang dapat memunculkan makna hidup sesuai dengan kemampuan yang mereka miliki. Pada sesi ke 4 atau pada saat melakukan evaluasi hampir semua responden sudah mempunyai makna hidup dan mempunyai harapan untuk masa depan yang lebih baik sehingga mereka tidak merasa sedih, malu ataupun putus asa selama menjalani kehidupan di dalam lapas.

Hal itu sesuai dengan pernyataan James C. Crumbaugh dalam Bastaman (2007) bahwa ada 5 cara untuk menemukan makna hidup yaitu melalui pemahaman diri, bertindak positif, pengakraban hubungan, pengalaman dan ibadah. Kegiatan tersebut tidak harus yang rumit akan tetapi dapat dimulai dari kegiatan yang sederhana (Frankl, 1999). Menurut beliau hal tersebut bermanfaat untuk meningkatkan motivasi hidup, menjaga perilaku adaptif, mengurangi rasa bosan/jenuh dan menimbulkan rasa bahagia. Fromm (1997) mendukung pernyataan Frakl bahwa salah satu cara untuk mempertahankan keberadaan diri secara alami dan menemukan makna hidup di dalamnya adalah melalui hasil kegiatan/kerja yang kreatif dan inovatif.

Keberhasilan penurunan tingkat keputusasaan narapidana wanita pada kelompok intervensi dan kelompok kontrol setelah pemberian 
logotherapy ini juga dikarenakan sebelumnya responden telah diikutsertakan dengan banyak kegiatan dan keterampilan di dalam lapas seperti keterampilan menjahit, menyulam, menyalon, pengajian, olahraga, membersihkan lapangan dan lain sebagainya sehingga memudahkan bagi responden untuk memillih dan melakukan kegiatan yang dapat memberikan makna bagi diri dan hidupnya.

Melihat pengaruh dari logotherapy tersebut, maka sudah seharusnya perawat dapat memberikan asuhan keperawatannya dalam menangani berbagai macam masalah yang terjadi pada narapidana wanita baik secara fisik maupun psikologisnya. Karena salah satu tugas perawat adalah memberikan asuhan keperawatan secara komprehensif melalui bio-psiko-sosio dan spiritual. Pemberian asuhan keperawatan ini menggunakan proses keperawatan yang dimulai dari pengkajian sampai evaluasi. Selain daripada itu bentuk asuhan keperawatan yang diberikan perawat, dapat berupa psikoterapi dan untuk tindakan psikoterapi ini sudah diatur dalam peraturan menteri kesehatan Republik Indonesia nomor 1109/MENKES/PER/IX/2007 sehingga sudah jelas aspek legalnya.

\section{Perubahan tingkat keputusasaan pada kelompok kontrol antara pre test dan post test}

Hasil penelitian menunjukkan bahwa ada perubahan tingkat keputusasaan pada kelompok kontrol antara pre test dan post test dengan nilai $p$ value $0,001>0,05$. Penurunan tingkat keputusasaan pada kelompok kontrol sebesar 2,57. Pada kelompok kontrol antara pre dan post test tidak dilakukan intervensi karena takutnya akan mengakibatkan bias dari hasil penelitian. Terapi pada kelompok kontrol diberikan setelah dilakukan post test. Terapi yang diberikan berupa terapi generalis yaitu (Assesment keputusasaan dan latihan berfikir positif melalui penemuan harapan dan makna hidup) selama satu kali pertemuan. Meskipun tidak dilakukan terapi ternyata hasilnya menunjukkan ada penurunan tingkat keputusasaan pada kelompok kontrol . Hal ini dapat disebabkan karena responden kelompok kontrol juga tinggal satu tempat dengan responden yang diberikan intervensi sehingga ada kemungkinan untuk terpaparnya intervensi logotherapy pada kelompok kontrol oleh kelompok intervensi.

\section{KESIMPULAN}

Dari hasil penelitian didapatkan hasil tidak ada perbedaan tingkat keputusasaan antara kelompok intervensi dan kelompok kontrol sebelum dilakukan logotherapy dan ada perbedaan tingkat keputusasaan antara kelompok intervensi dan kelompok kontrol setelah dilakukan terapi. Pada kelompok intervensi antara sebelum dan setelah dilakukan logotherapy didapatkan penurunan tingkat keputusasaan yang signifikan. Penurunan skor rata-rata keputusasaan pada narapidana wanita setelah dilakukan logotherapy adalah 3 kali lipat dibandingkan dengan sebelum dilakukan logotherapy. Pada kelompok kontrol meskipun tidak dilakukan intervensi, terdapat penurunan tingkat keputusasaan antara pre test dan post tes. Penurunan skor rata-rata keputusasaan pada narapidana wanita kelompok kontrol adalah satu kali lipat dibandingkan dengan kelompok intervensi yang dilakukan logotherapy. Dengan demikian dapat disimpulkan bahwa logotherapy ada pengaruhnya dalam menurunkan tingkat keputusasaan pada narapidana wanita di lapas wanita Kelas IIA Bandung.

\section{DAFTAR PUSTAKA}

Abela, J. R. Z \& Brozina. (2006). Depressive Mood Reactions to Failure in the 
Achievement Domain: A Test of the Integration of the Hopelessness and Self-esteem Theories of Depression. Cognitive Therapy and Research, 26(4), 531-552.

Bastaman, H. D. (2007). Logoterapi: Psikologi untuk Menemukan Makna Hidup dan Meraih Hidup Bermakna. Jakarta: Raja Grafindo Persada.

Beck, A.T., Weissman, A., Lester, D., \& Trexler, L. (1974). The Measurement of Pessimism: The hopelessness Scale. Journal of Consulting and Cilinical Psychology, 42 (6), 861-865.

Charlotte, Y., and Jane, L.I. (2012). Exploring Application of the InterpersonalPsychological Theory of Suicidal Behavior to Self-injurious Behavior among Women Prisoners: Proposing a New Model of Understanding. International Journal of law and psyciatry, 35, 70-76.

Dunn, S.L. (2005). Hopelessness as a Response to Physical Illness. Journal of Nursing Scholarship, 37 (2), 148154.

Forintos, D.P, Sallai J., Rozsa. S., (2010) Adaptation of the Beck Hopelessness Scale in Hungary. Department of Clinical Psychology, Hungary Topics, 19 (2010), 2, 307-321.

Frankl, V.E. (1965). The Concept of Man in Logotherapy. Journal of Existentialism, Vol. VI, pp. 53-55.

Kimble, M.A \& Ellor, J.W. (2000). Logotherapy: An Overview. Reprinted from Viktor Frankl's Contribution to Spirituality and Aging, a monograph published simultaneously. The Journal of Religious Gerontology, Vol. 11, No. 3, pp. 8-24.
Kylma, J. (2005). Despair and Hopelessness in the Context of HIV- a Metasyntesis on Qualitative Research Finding. Journal of Clinical Nursing, 14, 814821.

Levine, R. (2007). Treating Idealized Hope and Hopelessness. International Journal of Group Psychotherapy, 57(3), 297-317.

Marshall.M. (2011). Prism of Meaning; Guide to the Fundamental Principles Logotherapy. Januari 25, 2015. www.Logotherapy.org.

Marsiglia, F. R., Kulis, S., Perez, H. G., \& Bermudez-Parsai, M. (2011). Hopelessness, Family Stress, and Depression among Mexican-heritage Mothers in the Southwest. Health \& Social Work, 36(1), 7-18.

Mystakidou, K., Tsilika, E., Parpa, E., Pathiaki, M., Patiraki, E., Galanos, A., et al. (2008). Preparatory Grief, Psychological Distress and Hopelessness in Advance Cancer Patient. European Journal of Cancer Care. 17, 145-151.

Smith, Aaron. (2012). Innovative Application of Logotherapy for Military Related PTSD. Paper based on program presented. ACA Conference, San Fransisco.

Varcarolis, E.M. (2006). Psychiatric Nursing Clinical Guide: Assessment Tools and Diagnosis. Philadepghia. W.B saunders Co.

Videbeck, S.L. (2008). Psychiatric Mental Health Nursing. $\left(4^{\text {rd }}\right.$ Ed). Philadhelpia: Lippincottt Williams \& Wilkins. 